\title{
PENENTUAN PIAWAIAN ALKOHOL DALAM MAKANAN YANG DIBENARKAN DARI PERSPEKTIF ISLAM
}

\author{
Anisah Ab Ghani* \\ Muhammad Safiri Ismail ${ }^{* *}$
}

\begin{abstract}
The issue of alcohol used in food is still a polemic in the Muslim community because of the perception that alcohol is khamr (alcoholic beverage). This perception is not actually accurate because alcohol and khamr are different. This article discusses the issue of foods containing alcohol, which cannot be evaluated based solely on the percentage of alcohol content, but must also be based on the extent of its capasity to cause intoxication or harm. The rate of the $0.01 \%$ alcohol content standard set by JAKIM also needs to be reviewed as it is not considered to be practical or realistic for most of the halal fermented food market, which contains up to 5\% alcohol. From the medical perspective, the potential for drunkenness in someone is also affected by the alcohol concentration, the rate of consumption, body weight, gender, age and alcohol consumption with food or on its own.
\end{abstract}

Keywords: Alcohol, Standard of Alcohol in Food, Islamic Law of Food, Khamr, Alcoholic Beverage.

\footnotetext{
* Profesor Madya, Jabatan Fiqh \& Usul, Akademi Pengajian Islam, Universiti Malaya, Kuala Lumpur.

** Felo SLAI, Jabatan Fiqh \& Usul, Akademi Pengajian Islam, Universiti Malaya, Kuala Lumpur.
} 


\section{PENDAHULUAN}

Secara umumnya, isu penggunaan alkohol dalam barangan kepenggunaan masih menjadi polemik yang mengelirukan masyarakat sehinggalah ke hari ini. Kekeliruan ini bukan hanya melibatkan golongan masyarakat awam bahkan juga kelompok ahli akademik dan para ulama. Dalam hal ini, golongan yang terlibat dapat dibahagikan sekurang-kurangnya kepada dua golongan. Pertama; golongan yang mendakwa alkohol adalah bahan najis yang menyamai arak lantas ia dihukumkan sebagai haram. Kedua; golongan yang menganggap alkohol suci kerana ia berbeza daripada arak sekalipun tidak dinafikan ia adalah kandungan utama dalam komposisi arak.

Alkohol biasanya terhasil secara semula jadi dalam sesetengah produk makanan rutin yang halal dimakan seperti tapai, tempe dan kicap. Selain itu, ia juga boleh dihasilkan secara buatan dalam makmal atau kilang khusus seperti etanol yang digunakan dalam pemprosesan pelbagai produk kepenggunaan di pasaran bahkan juga boleh dicampurkan dalam arak. Justeru itu, timbul persoalan adakah alkohol yang wujud dalam produk makanan halal berbeza daripada alkohol dalam arak, lantas wujud perbezaan hukum di antara kedua-duanya. Sebaliknya, jika sifat kedua-dua jenis alkohol dalam kedua-dua bahan tersebut adalah sama maka apakah pula faktor sebenar atau 'illah' ${ }^{l}$ yang membezakan hukum arak berbanding produk makanan yang halal sedangkan masing-masing mengandungi bahan alkohol yang sama contohnya etanol.

Oleh yang demikian, artikel ini cuba membincangkan konsep alkohol yang terkandung dalam produk kepenggunaan terutamanya makanan dan sejauh mana kaitannya dengan alkohol dalam arak. Kadar penentuan piawaian alkohol yang dibenarkan dalam makanan terutamanya bagi tujuan penetapan hukum sama ada ianya halal dimakan atau tidak juga akan dibahaskan dakam penulisan ini.

'Illah boleh disimpulkan sebagai suatu ciri zahir yang konsisten yang wujud pada sesuatu bahan yang mana ia akan menentukan bentuk hukum terhadap bahan tersebut. Al-Zuhaylī, Wahbah, Ușūl al-Fiqh al-Islamī, (Damshiq: Dār al-Fikr, 1986) juz. 1, h. 646-649. 


\section{KONSEP ARAK (AL-KHAMR) MENURUT FIQH}

Jika tinjau dari sudut penggunaan bahasa Arab, arak atau khamr boleh diertikan dengan pelbagai maksud antaranya seperti penutupan (taghtiyah), percampuran (mukhalațah), perubahan (taghayyur), cukup masa (idrāk wa bulügh al-awan) dan meninggalkan (tark). ${ }^{2}$ Namun demikian, maksud yang paling serasi dengan khamr ialah penutupan dan percampuran seperti yang ditegaskan oleh Ibn al-'Arabi memandangkan sifat khamr mampu menutup fungsi akal dan mencampur-adukkan pemikiran manusia sehingga menghilangkan kewarasannya. ${ }^{3}$ Dalam Kamus Dewan Bahasa dan Pustaka, arak atau khamr didefinisikan sebagai minuman yang mengandungi alkohol atau minuman keras. ${ }^{4}$

Dari sudut istilahnya, jumhur ulama telah mendefinisikan arak sebagai apa jua bahan yang mampu memabukkan dan menghilangkan kewarasan akal. Pandangan ini adalah berdasarkan hadis yang telah diriwayatkan oleh Ibn 'Umar daripada Rasulullah SAW yang bersabda:

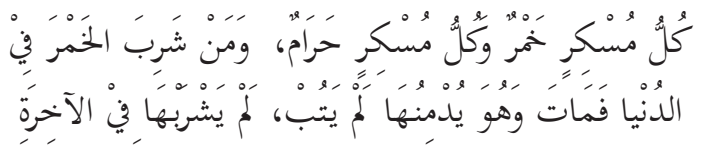

"Setiap bahan yang memabukkan itu adalah arak dan setiap bahan yang memabukkan itu adalah haram, dan sesiapa yang meminum arak di dunia lalu dia meninggal dunia dalam keadaan dia menagihnya (dan) tidak (sempat) bertaubat nescaya (sebagai balasan) dia tidak akan dapat meminumnya di akhirat kelak". 5

2 Ibn Manzūr, Lisān Al-'Arab, (Kaherah: Dār al-Ma'ārif, t.t.), jld.14, h. 1259.

3 Al-Ḥasīīi, Sabīb bin Alī, Al-Khamr (Mekah: t.p., t.t.), h. 31.

4 Noresah bt. Baharom et. al, Kamus Dewan, (Kuala Lumpur: Dewan Bahasa dan Pustaka, 2007), h. 75.

5 Muslim, Abū al-Husayn b. al-Hajjaj (2000), Sahīh Muslim, Kitāb alAshribah, no. h.: 2003. Lihat al-'Asqalānī, Ibn. Hajar Aḥmad b. 'Alī (1991), Fath al-Bārī bi Sharh Sạ̄ịh al-Bukhārī Li Abī 'Abd Allah Muhammad b. Ismā'il al-Bukhārī, Kitāb al-Ashribah, no.h.: 5585, 5586. 
Dalam mengulas hadis di atas, Imam Nawawi menjelaskan bahawa Nabi SAW telah mengharamkan semua perahan buahbuahan atau minuman yang memabukkan kerana ia dianggap sebagai arak. Pengharaman ini tidak mengira sama ada minuman tersebut daripada kategori arak yang dihasilkan daripada alfadikh (kurma muda), al-tamar (kurma kering), al-rutab (kurma masak), al-zabīb (anggur), al-sha'īr (barli), a-'asal (madu) atau sebagainya. Pandangan ini dipegang oleh kebanyakan ulama daripada pendokong mazhab Shafii, Maliki dan juga Hanbali. Namun, golongan 'Irāqiyyūn terutamanya ulama bermazhab Hanafi berpandangan sebaliknya apabila mereka menghadkan penafsiran khamr sebagai minuman yang memabuk daripada perahan anggur sahaja. ${ }^{6}$

Walau bagaimanapun, di sebalik perselisihan ulama dalam mendefinisikan perkataan khamr, kesemua mereka sepakat menegaskan bahawa semua minuman yang memabukkan sama ada ianya dihasilkan daripada perahan anggur atau tidak adalah haram dan tidak boleh pertikaikan sejak daripada zaman para Sahabat RA lagi. Jika ada pihak yang mengingkarinya maka mereka dihukumkan murtad kerana seolah-olah memperdustakan Nabi SAW lantaran menafikan suatu perkara yang asasi dalam Islam. ${ }^{7}$ Hal ini adalah berdasarkan kepada beberapa ayat al-Quran yang menyatakan pengharaman arak secara jelas terutamanya seperti firman Allah SWT:

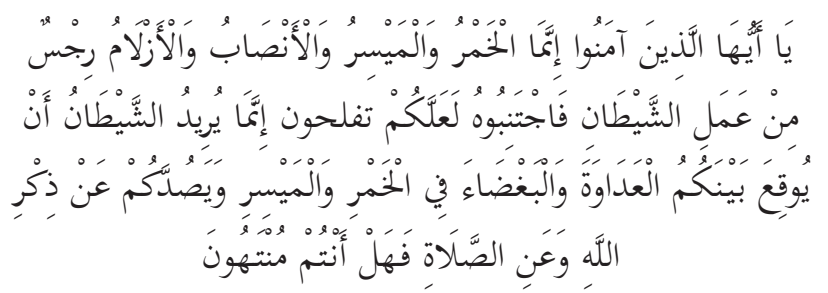

"Wahai orang-orang yang beriman! Bahawa sesungguhnya arak, dan judi, dan pemujaan

6 Zaydān, 'Abd al-Karīm, al-Mufașṣal fi Ahkām al-Mar'ah wa al-Bayt al-Muslim fì al-Shar 'īah al-Islämiyyah, (Baghdad: Mu'assasah alRisālah, t.t.) jld. 3, h. 58

7 Ibn Qudāmah, 'Abd Allah b. Muḥammad, al-Mughnī, (Riyaḍ: Dār 'Alam al-Kutub, t.t.), juz. 12, h. 493-494. 
berhala, dan mengundi nasib dengan batangbatang anak panah, adalah (semuanya) kotor (keji) dari perbuatan Syaitan. Oleh itu hendaklah kamu menjauhinya supaya kamu berjaya. Sesungguhnya Syaitan itu hanyalah bermaksud mahu menimbulkan permusuhan dan kebencian di antara kamu dengan sebab arak dan judi, dan mahu memalingkan kamu daripada mengingati Allah dan daripada mengerjakan sembahyang. Oleh itu, mahukah kamu berhenti (daripada melakukan perkara-perkara yang keji dan kotor itu atau kamu masih berdegil)?"

Surah al-Mā'idah (5): 90-91

Rasulullah SAW sendiri juga berulang-kali menegaskan pengharamannya sehinggakan baginda mengaitkan laknat Allah SWT terhadap individu yang mempunyai kaitan dengan arak:

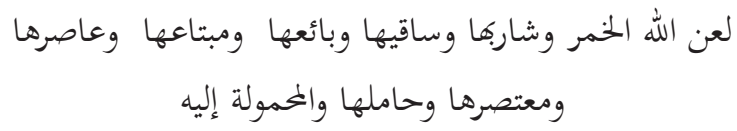

“Allah SWT telah melaknatarak, peminumnya, penuangnya, penjualnya, pembelinya, pemerahnya (pengeluar), pelanggan yang meminta ia diperah, pembawanya dan pelanggan yang meminta ia dibawakan kepadanya". ${ }^{8}$

\section{PERSELISIHAN FUQAHA' TERHADAP DEFINISI KHAMR}

Menurut Imam Abu Hanifah, khamr merujuk kepada perahan anggur yang diperam sehingga ianya keruh bergelora dan berbuih seolah-olah mendidih dan buih tersebut kemudiannya hilang. ${ }^{9}$ Ini adalah pendapat pertama yang diutarakan dalam mazhab Hanafi.

8 Al-Saharanfuri, Khalīl Aḥmad (t.t.), Badhl al-Majhūd fì Hāal Sunan Abī Dāwūd li Abī Dāwūd, Kitāb al-Ashribah, no. h.: 3674.

9 Al-Sarakhsī, al-Mabsūṭ, (Beirut: Dār al-Ma'rifah, t.t.), jld. 24, h. 18. 
Pandangan kedua dalam mazhab Hanafi iaitu Abū Yūsuf dan Muḥammad b. Hasan al-Shaybān̄̄ menyatakan bahawa sesuatu minuman sudah boleh dianggap sebagai arak (khamr) apabila perahan anggur tersebut telah bergelora sekalipun tidak sampai kepada tahap berbuih dan buihnya hilang. Pandangan ini dianggap paling rajih dalam mazhab Hanafi. ${ }^{10}$

Ulama bermazhab Hanafi menegaskan arak adalah tetap haram diminum tanpa mengira sama ada ianya sedikit mahupun banyak atau sama ada ia menyebabkan mabuk atau tidak. Sebaliknya, mereka hanya membezakan hukum arak dalam perlaksanaan hudud iaitu jika seseorang meminum arak daripada sumber anggur maka dia dikenakan hukuman 80 kali sebatan walaupun dia tidak mengalami kemabukan. Akan tetapi, jika dia meminum sedikit arak daripada perahan selain anggur yang dipanggil nabiz maka dia tidak dikenakan hukuman hudud namun tetap dikenakan hukuman ta' ${ }^{\text {zir. }}{ }^{11}$

Walau bagaimanapun, pandangan di atas telah dinafikan oleh ulama jumhur kerana mereka menegaskan pengertian arak (khamr) tidak hanya terbatas kepada perahan anggur semata-mata, tetapi sebaliknya juga merangkumi semua minuman yang memabukkan. Ini termasuk perahan daripada buah kurma, kismis, madu, gandum, barli, beras dan sebagainya. ${ }^{12}$ Pandangan ini sebenarnya dilihat lebih rajih berdasarkan dalil-dalil yang jelas yang telah dikemukakan sebelum ini seperti sabda Rasulullah SAW yang menyatakan bahawa arak merujuk kepada apa jua bahan yang boleh memabukkan. Ini ditambah lagi dengan pandangan para Sahabat RA seperti yang diriwayatkan oleh Imam al-Bukhārī mengenai kata-kata Saydina 'Umar b. Al-Khaț̣āb dalam khutbahnya:

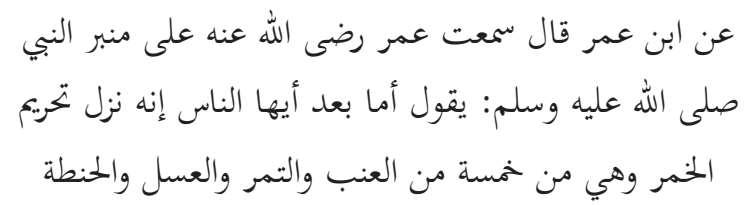

10 Al-Kasāni, 'Alā Al-Dīn, Badā 'i' al-Șanā'i' ', (Beirut: Dār Kutub al'Arabī, 1982), jld. 5, h. 112.

11 Al-Zuḥaylī, Wahbah, al-Fiqh al-Islām wa Adillatuh, (Damsyik: Dār al-Fikr, 1985) jld. 3, h. 536-537

12 Al-Shīrāzī, al-Muhazzab, (Beirut: Dār al-Fikr, t.t.), jld. 2, h. 287. 


$$
\text { والشعير والخمر ما خامر العقل }
$$

Daripada Ibnu 'UmarRA berkata: "Aku mendengar Saydina 'Umar RA ketika beliau berada di atas mimbar Rasulullah SAW berkata: Wahai sekalian manusia! Sesungguhnya telah datang pengharaman arak dan ianya daripada lima perkara iaitu anggur, kurma, madu, gandum dan barli. Dan arak itu adalah suatu minuman yang menutup (kewarasan) akal". ${ }^{13}$

Berdasarkan pandangan Saydina 'Umar di atas, pengharaman arak bukan semata-mata berasaskan sifat zahir minuman berkenaan sama ada ianya dihasilkan daripada anggur mahupun tidak. Sebaliknya, pengharaman arak bergantung kepada faktor 'illah yang menyebabkan pengharamannya iaitu memabukkan. Lantaran itu, apa jua minuman mahupun bahan pepejal yang mampu memabukkan dan menafikan kewarasan akal boleh dihukumkan sebagai arak yang diharamkan. ${ }^{14}$ Ini merangkumi kesemua jenis arak sama ada yang biasa dihasilkan secara tradisi seperti nabiz, fadikh, sakr, bit'u, tala', baziq, munassaf, naqi', mizar, khalitān, ji 'ah dan ghubayra' atau dihasilkan pada masa sekarang seperti bir, wain, wiski, vodka, rum, brandi dan sebagainya. Penjenamaan arak dengan nama yang berbeza di atas sebenarnya bukanlah suatu perkara yang pelik memandangkan Rasulullah SAW sendiri pernah menegaskannya sebagai cubaan untuk menghalalkan arak. ${ }^{15}$

Kesimpulannya, walaupun arak yang dihasilkan dilabelkan dengan nama yang berbeza disebabkan perbezaan sumber gula atau kanji yang digunakan, namun konsep dalam proses penghasilannya adalah tetap sama iaitu penapaian dan penyulingan. Sebaliknya,

13 Al-Bukhārī, Muhammad bin Ismā’il, Ṣaḥ̄ḥ al-Bukhārī, Kitāb AlAshribah, no. h.: 4253.

14 Al-Kasān̄i, Badā' 'í al-Șanā'i', jld. 6, h. 458. Lihat Zaydān, Abd Karīm, jld. 3. h. 58.

15 Ini berdasarkan kepada sabda Rasulullah SAW: "Malam dan siang tidak berlalu melainkan ada segolongan manusia daripada umatku yang meminum arak, mereka menamakan arak tadi dengan nama selain daripada namanya yang asal" (untuk tujuan menghalalkannya). Lihat Ibn Majah (1954), Sunan Ibn Mājah, Kitāb al-Ashribah, no. h.: 3384. Lihat al-Dārīmī (t.t.), Sunan al-Dārīmī, Kitāb al-Ashribah, no. h.: 2100 . 
elemen yang membezakan sesuatu arak dengan jenis arak yang lain ialah daripada sudut tahap kelikatan alkohol dalam minuman itu tersebut. Dalam hal ini, arak yang dihasilkan menerusi proses penyulingan dilihat memiliki kadar kelikatan alkohol yang lebih tinggi berbanding arak yang hanya dihasil melalui proses penapaian yang biasa.

\section{KONSEP ALKOHOL}

Dari sudut bahasa, alkohol berasal daripada perkataan Bahasa Arab "Alghol" yang bermaksud sesuatu yang memabukkan atau merosakkan akal. Ia juga dikatakan berasal daripada kata nama terbitan " $k u h l$ ". Perkataan 'al-kuhl' digunakan oleh ahli kimia Arab untuk merujuk kepada serbuk halus yang terhasil melalui beberapa cara termasuklah proses memanaskan sesuatu bahan sehingga menjadi gas atau wap dan kemudiannya melalui proses penyejukan. ${ }^{16}$

Dari sudut ilmu kimia, alkohol diertikan sebagai sebatian organik atau hidrokarbon yang mempunyai kumpulan fungsi $(-\mathrm{OH}) .{ }^{17}$ Alkohol juga boleh dianggap sebagai satu sebatian organik yang hampir sama dengan air. Salah satu daripada atom hidrogen dalam air digantikan dengan kumpulan alkil (tepu).

Molekul hidrokarbon yang kecil adalah dalam bentuk gas manakala molekulnya yang besar akan membentuk cecair. Dari bahan alkana seperti metana dan etana akan menjadi methanol dan etanol kerana alkohol boleh terbentuk dengan termasuknya kumpulan fungsi $\mathrm{OH}$. Nama alkohol tersebut mengikut nama alkana ditambah dengan "nol" bagi menunjukkan ia adalah alkohol. ${ }^{18}$ Ia mempunyai formula amnya sebagai $\mathrm{R}-\mathrm{OH}^{19}$. $\mathrm{R}$ adalah merujuk kepada kumpulan alkil.

16 John John A. Monick, Alkohol: Their Chemistry, Properties and Manufacture (USA: Reinhold Book Corporation, 1968), h. 4.

17 Bohari Mohd Yatim, "Alkohol Sebagai Bahan Kimia dan Kegunaannya dalam Kehidupan", Isu-isu Syariah dan Undangundang, (1988): h. 37.

18 Ibid.

19 Mustaffa bin Ahmad, Pengenalan Kimia Organik, (Perak: Universiti Pendidikan Sultan Idris, 2004), h. 147. 
Menurut kamus Dewan Bahasa dan Pustaka, alkohol didefinisikan sebagai cecair yang mudah terbakar dan juga memabukkan (terdapat di dalam minuman keras dan lain-lain). Ia juga bererti minuman keras. ${ }^{20}$ Menurut kamus Webster's New World pula, alkohol didefinisikan sebagai: ${ }^{21}$

i. Suatu cecair yang tidak berwarna dan mudah meruwap.

ii. Cecair $(\mathrm{C} 2 \mathrm{H} 5 \mathrm{OH})$, yang mudah terbakar seperti bensin, digunakan di dalam industri dan perubatan.

iii. Elemen yang memabukkan daripada minuman wiski, anggur, bir, dan minuman keras yang melalui proses fermentasi atau sulingan lainnya, dan juga dikenali sebagai alkohol etil atau ethanol.

\section{JENIS-JENIS ALKOHOL}

Alkohol boleh dibahagikan kepada beberapa kumpulan iaitu alkohol monohidrik, alkohol dihidrik, gula alkohol dan alkohol lemak.

i. Alkohol monohidrik

Alkohol monohidrik adalah alkohol yang mengandungi satu kumpulan hidroksil (-OH). Terdapat lima jenis alkohol monohidrik iaitu metanol (spirit kayu), etanol, propanol, butanol dan pentanol. Sebagai contoh, metanol adalah bahan yang beracun dan tidak boleh digunakan oleh manusia. Metanol mudah meruwap. Cecairnya tidak berwarna dan mudah terbakar. Dos maut untuk metanol ialah $0.65 \%$. Etanol pula dikenali sebagai alkohol bijirin atau alkohol minuman. Ia tidak berwarna serta mudah terbakar dan mempunyai sedikit sifat toksik dan beracun. Ia lebih biasa digunakan dalam makanan berbanding jenis alkohol lain kerana

20 Noresah bt. Baharom et. al., Kamus Dewan, h. 37.

21 A Simon \& Schuster Macmillan Company, Webster's New World College Dictionary Third Edition, 14 Julai 2009, http://www. tftwindo.org/livingwords/SH132005/132005-3.htm. 
rasa dan aromanya yang menarik. Dos maut bagi etanol adalah $0.71 \%$ berdasarkan data keselamatan bahan. ${ }^{22}$

ii. Alkohol dihidrik

Alkohol dihidrik adalah molekul alkohol dengan dua kumpulan hidroksil (-OH) pada atom karbonnya. Secara umumnya, alkohol jenis ini tergolong dalam kumpulan diol atau glikol seperti ethylene glycol (EG) dan propylene glycol (PG). Kedua-dua jenis alkohol ini adalah merupakan cecair sintetik yang tidak bewarna, tidak berbau dan boleh menyerap air. Sehubungan dengan ini, PG banyak digunakan dalam produk makanan seperti aiskrim rendah lemak selain daripada berfungsi sebagai pelarut warna dan juga perasa. EG pula adalah bahan yang biasa digunakan sebagai agen anti sejuk beku. Kadar ketoksikan yang lebih tinggi. Oleh yang demikian, penggunaan PG dalam makanan adalah lebih sesuai berbanding EG memandangkan dos maut bagi PG adalah 2.2\%. ${ }^{23}$

iii. Gula alkohol

Gula alkohol adalah sebatian karbohidrat tetapi bukan gula atau alkohol. Ia wujud secara semula jadi dalam tumbuh-tumbuhan dan banyak digunakan sebagai pengganti gula dalam makanan kerana kandungan kalorinya yang rendah. Gula alkohol yang biasa digunakan adalah seperti maltitol, xylitol, sorbitol, gliserol, isomalt dan sebagainya. Sebagai contoh, sorbitol adalah pemanis yang boleh didapati dalam pelbagai produk makanan. Ia berfungsi sebagai agen untuk mengekalkan kelembapan makanan. Gliserol pula dikenali sebagai gliserin. Ia merupakan sebatian yang tidak mempunyai bau dan warna tetapi memiliki rasa yang manis. Ia berfungsi sebagai pelembab dalam produk kosmetik. ${ }^{24}$

iv. Alkohol lemak

Alkohol lemak adalah alkohol yang berasal daripada asid lemak

22 Dzulkifly Mat Hashim dan Nurul Hayati Abdul Hamid, "Penjenisan Alkohol dan Kesan Penggunaannya Dalam Makanan dan Minuman," Jurnal Halal, (2008), h. 21-22.

23 Ibid., h. 22-23.

24 Ibid., h. 24. 
atau metal ester daripada kelapa, kelapa sawit, isirung kelapa sawit atau lemak khinzir. Ia berfungsi sebagai pemekat dalam bahan makanan dan juga kosmetik. ${ }^{25}$

\section{PROSES PENGHASILAN ETANOL ATAU ETIL ALKOHOL}

Etanol merupakan bahan kimia organik yang tertua pernah disentesis dan digunakan oleh manusia memandangkan kegunaannya yang sangat luas seperti sebagai pelarut, perasa, penstabil dan sebagainya. Etanol yang juga boleh dikenali sebagai alkohol minuman ini biasanya dihasilkan menerusi cara penapaian atau fermentasi gula dari pelbagai sumber seperti molasses, air tebu dan lain-lain. Secara ringkasnya, proses fermentasi dalam penghasilan etanol adalah seperti berikut:

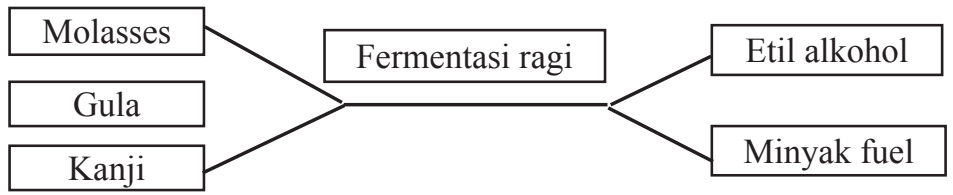

Secara konsepnya, proses fermentasi atau penapaian adalah proses biasa yang sudah lama diaplikasikan sejak awal kewujudan manusia lagi. Yang membezakan setiap proses fermentasi tersebut adalah dari sudut sumber gula dan ragi yang digunakan. Antara ragi atau agen penapaian yang biasa digunakan adalah daripada spesis yis atau soccharomyces yang berasal dari pecahan perkataan Greek "saccharos", bererti gula dan "mykos" yang bererti yis. ${ }^{26}$

Sehubungan dengan ini, satu kumpulan penyelidik yang diketuai oleh Prof. Madya Dr. Anisah Ab. Ghani telah melakukan lawatan ke kilang penghasilan etanol yang dimiliki oleh Syarikat Fermpro Sdn. Bhd., Chuping, Kangar Perlis untuk melihat sendiri

25 Ibid.

26 Bohari Mohd Yatim, "Alkohol Sebagai Bahan Kimia dan Kegunannya Dalam Kehidupan”, Isu-isu Syariah dan Undang-undang, (1988): h. 40-41. 
proses penghasilan etanol dan menemubual Pengurus Makmal syarikat berkenaan iaitu En. Khairul Akhbar Ahmad Zabidi. ${ }^{27}$

En. Khairul Akhbar menjelaskan bahawa kilang Fermpro telah menghasilkan etanol dalam dua keadaan iaitu etanol 95\% v/v dan etanol $100 \% \mathrm{v} / \mathrm{v}$. Pembahagian ini dibuat mengikut keperluan dan kegunaan sesuatu industri yang berbeza-beza termasuklah industri penghasilan makanan. Selain itu, beliau menjelaskan proses penghasilan etanol yang diamalkan di kilang beliau adalah menerusi cara penapaian molasses iaitu sisa lebihan daripada air tebu daripada kilang penghasilan gula di sekitar Chuping, Perlis.

Beliau menegaskan lagi bahawa etanol yang dihasilkan melalui proses lain seperti peretakan petroleum adalah tidak sesuai untuk digunakan dalam hal-hal yang berkaitan dengan perubatan atau pemakanan kerana bahan-bahan terlarut yang ada padanya boleh dikategorikan sebagai beracun dan tidak boleh dinyah-buangkan $100 \%$ serta boleh memberi kesan negatif kepada kesihatan. Justeru itu, kebanyakan daripada etanol daripada proses ini digunakan dalam penghasilan ethelene iaitu bahan asas dalam pembuatan plastik.

Dalam amalan pemprosesan etanol yang dilakukan oleh Syarikat Fermpro, ia melibatkan banyak peringkat antaranya seperti berikut:

Peringkat 1: Tangki A: Molasses Strorage Tank: Iaitu tangki penyimpanan Molasses ( sisa gula tebu yang pekat) yang diperolehi daripada kilang penghasilan gula.

Peringkat 2: Tangki B: Molasses Dilution Tank: Iaitu tangki yang digunakan untuk mencairkan kepekatan molasses kepada tahap yang diperlukan. Molasses perlu diuji kerana kandungannya mungkin berbeza.

Peringkat 3: Tangki C: Yeast Culture Tank: Iaitu tangki yang

27 Temubual bersama En. Khairul Akhbar Ahmad Zabidi sebagai Pengurus Makmal Fermpro Sdn. Bhd. bertempat di kilang berkenaan di Lot 2, Kawasan Perindustrian Chuping, Kangar Perlis, pada 29 Julai 2009 bersamaan hari Rabu pada jam 1 tengah hari hingga 3 petang. 
digunakan untuk mencampurkan molasses dengan yis. Sebelum kedua-duanya dicampurkan dalam tangki ini, yis terlebih dahulu perlu dibiakkan. Oleh yang demikian, sebanyak $10 \mathrm{~kg}$ yis di masukkan ke dalam tangki tersebut bersama-sama baja urea supaya ia dapat menggalakkan pembiakan yis sehingga mencapai $400 \mathrm{~kg}$ yis. Dalam proses ini, yis yang merupakan agen penapaian perlu dijaga dengan sebaiknya di mana setiap 1 jam, peratusan yis yang telah terhasil perlu diuji.

Peringkat 4: Tangki D: Fermentation Tank: Iaitu tangki untuk menjalankan proses fermentasi.

Setelah yis berjaya dibiakkan, molasses 'akan dicampurkan dan proses penapaian akan bermula. Jangkamasa yang diperlukan adalah selama 24 hingga 30 jam. Dalam proses ini, molasses akan diuraikan oleh yis menjadi etanol.

Peringkat 5: Tangki E: Degassing Column: Tangki ini berperanan untuk mengasingkan bahan-bahan yang mudah meruap seperti air daripada campuran etanol yang telah terhasil.

Peringkat 6: Tangki F: Purifying Column: Tangki ini dikenali sebagai tangki penyulingan. Selepas proses pengasingan bahanbahan dijalankan di tangki E, proses seterusnya ialah penyulingan bahan-bahan hasil daripada tangki E.

Peringkat 7: Tangki G: Rectifying Column: Selepas menjalani proses di tangki $\mathrm{F}$, etanol yang telah disuling kemudiannya akan ditingkatkan tahap ketulenannya (konsentrasi) kepada tahap yang diperlukan iaitu daripada $60 \%$ kepada $95 \%$.

Peringkat 8: Tangki H: Dehydrating Column: Proses seterusnya ialah proses pengeringan. Ia bertujuan untuk mendapat etanol yang mempunyai tahap konsentrasi 100\%.

Peringkat 9: Tangki I: Recovery Column: Tangki ini berperanan untuk mengasingkan lebihan daripada tangki $\mathrm{H}$ yang masih mempunyai air untuk disalurkan kepada tangki E semula bagi menjalani proses yang sama. 
Peringkat 10: Warehouse : Ia merujuk kepada gudang penyimpanan bagi alkohol dengan kepekatan 95\% dan 100\% mengikut kehendak pelanggan.

Tangki H: Waste Water Treatment: Proses untuk merawat sisa lebihan daripada proses penghasilan etanol. Sisa yang dimaksudkan dilihat seumpama hampas bersama air yang bewarna hitam yang boleh dijadikan baja tanaman.

\section{ARAK DAN ALKOHOL DARI PERSPEKTIF HUKUM ISLAM}

Tidak dinafikan bahawa alkohol atau lebih tepatnya, etanol adalah bahan asas yang wujud dalam arak. Namun begitu, kita wajib membezakan di antara kedua-duanya kerana kesan yang terhasil di sebalik pengambilan arak adalah berbeza dengan kesan daripada pengambilan etanol. Jika seseorang meminum arak, dia akan mengalami kemabukan sedangkan peminum etanol akan mengalami simptom keracunan sehingga boleh menyebabkan kematian.

Menurut En. Dzulkifly Mat Hashim yang merupakan Ketua Makmal Produk dan Proses Inovasi, Institut Penyelidikan Produk Halal, Universiti Putra Malaysia, Serdang dalam satu sesi temuramah bersamanya, pandangan yang menyamakan arak dengan etanol adalah suatu kesilapan kerana kedua-duanya adalah berbeza terutamanya dari sudut kimia. Ini kerana terdapat pelbagai jenis alkohol yang dihasilkan di pasaran yang kebanyakannya sudah digunakan sebagai pelarut dan penstabil bahan dalam sesuatu produk dan bukannya semata-mata untuk penghasilan arak. Menurut beliau lagi, rata-rata pengilang arak di Malaysia juga tidak berminat untuk menghasilkan alkohol sebagai produk mereka di samping arak kerana kos di sebalik pemprosesan etanol adalah lebih mahal dan lama berbanding proses penghasilan arak sedangkan harganya pula lebih murah daripada arak. ${ }^{28}$ Justeru

28 Temubual bersama En. Dzulkifly Mat Hashim, Ketua Makmal Produk dan Proses Inovasi, Institut Penyelidikan Produk Halal, Universiti Putra Malaysia, pada 13 Julai 2009 bersamaan hari Isnin pada jam 2.30 petang. 
itu, masyarakat Islam sepatutnya membuang tanggapan serong terhadap alkohol dan kilang yang menghasilkannya kerana mereka tidak semestinya mempunyai kaitan dengan penghasilan arak.

Sebagai contoh, kilang Fermpro di Chuping, Perlis tidak menghasilkan etanol untuk pengilang arak bahkan syarikat ini telah mendapat kelulusan halal secara rasmi daripada Jabatan Agama Islam Perlis setelah pemeriksaan menyeluruh dibuat terhadapnya. Namun demikian, pemantauan berterusan masih perlu dilakukan terhadap pengilang etanol kerana masih terdapat kemungkinan mereka akan menjualnya kepada pengilang arak seperti yang dilakukan oleh sebuah kilang etanol di Perak. Oleh yang demikian, penulis berpandangan pengilang etanol mentah sepatutnya diwajibkan membuat pengistiharan rasmi dalam perniagaan mereka untuk tidak mempunyai sebarang hubungan dengan industri arak. Pandangan ini bertujuan untuk mengelakkan industri etanol mentah daripada dipergunakan untuk menghasilkan arak sehingga memudaratkan masyarakat. Keadaan ini berlaku apabila etanol akan ditambah ke dalam arak untuk menambah tahap kelikatan etanolnya sama ada untuk tujuan menaikkan harga dan juga tahap kemabukan. Ini sejajar dengan kaedah hukum sadd al-dharī'ah yang menghalang sesuatu perkara daripada dilakukan sekalipun pada asalnya ia diharus. Ini dapat dilihat seperti dalam kes pengharaman menghina tuhan agama lain, menjual senjata kepada orang kafir ketika peperangan, menjual anggur kepada pengeluar arak dan sebagainya.

Selain itu, En. Dzulkifly Mat Hashim juga menegaskan proses penghasilan arak dan etanol adalah sama. Kedua-duanya melibatkan penapaian atau fermentasi. Sebagai contoh, dalam proses penghasilan arak, perahan anggur akan diperam sehingga ianya berbuih dan "menggila" mengikut tempoh masa tertentu bagi mendapatkan konsentrasi etanol padanya. Manakala proses penghasilan etanol juga melibatkan penapaian. Sisa gula tebu (molasses) akan diperam bersama yis sehingga larutannya berbuih dalam tempoh masa kira-kira 24 jam. Setelah itu, ia akan melalui proses penyulingan bagi mengasingkan etanol mentah daripada bendasing seperti yang diterangkan sebelum ini. Justeru itu, boleh dikatakan bahawa etanol mentah yang telah dihasilkan juga boleh dijadikan bahan untuk menghasilkan arak dengan cara mencampurkannya dengan air. Namun demikian, tidak boleh 
menganggap etanol adalah arak memandangkan sifatnya adalah beracun sedangkan arak bersifat memabukkan.

Oleh yang demikian, etanol yang dihasilkan untuk kegunaan industri contohnya sebagai pelarut, penstabil dan perisa adalah pada hakikatnya harus selagimana kadar etanol yang dicampurkan adalah terkawal dan tidak menyebabkan kemabukan atau keracunan. Selain itu, alkohol juga digunakan dalam bidang yang lebih kritikal seperti perubatan untuk mematikan kuman terutamanya ketika pembedahan. Justeru itu, kita sepatutnya tidak boleh menghukumkan bahawa alkohol adalah haram secara total kerana ia juga terhasil dalam sesetengah makanan halal yang melalui proses penapaian. Kadar peratusan etanol yang wujud di dalamnya adalah kira-kira 5\% seperti tapai beras. Selain tapai, makanan lain yang juga mengandungi etanol adalah tempe, budu, kicap, cencaluk dan sos, cuma kadar kandungan etanolnya tidaklah sebanyak etanol yang wujud dalam tapai. ${ }^{29}$

\section{KADAR PIAWAIAN PENGGUNAAN ALKOHOL DI DALAM MAKANAN}

Jika ditinjau dalam garis panduan hukum penggunaan alkohol yang paling terkini di Malaysia, JAKIM terutamanya menerusi Muzakarah Khas Jawatankuasa Fatwa Majlis Kebangsaan Bagi Hal Ehwal Ugama Islam Malaysia yang bersidang pada 14-16 Julai 2011 telah memutuskan mengenainya seperti berikut: ${ }^{30}$

Berdasarkan taklimat, pembentangan dan penjelasan yang disampaikan oleh pakar-pakar daripada Institut Penyelidikan Produk Halal, Universiti Putra Malaysia serta dengan mengambilkira keputusankeputusan yang telah diputuskan dalam Muzakarah Jawatankuasa Fatwa Majlis Kebangsaan Bagi

29 Nazih Hammad, Penggunaan Bahan-bahan yang Haram dan Najis di dalam Makanan \& Ubat-ubatan, terj. Dr. Basri bin Ibrahim AlHasani (Kuala Lumpur: Al-Hidayah Publishers, 2004), h. 74-75.

30 JAKIM, "Alkohol dalam makanan, minuman, pewangi dan ubatubatan.”, E-fatwa JAKIM. 8 Disember 2011. http://www.e-fatwa. gov.my/fatwa-kebangsaan/alkohol-dalam-makanan-minumanpewangi-dan-ubat-ubatan. 
Hal Ehwal Ugama Islam Malaysia terdahulu, Muzakarah Khas Jawatankuasa Fatwa Majlis Kebangsaan Bagi Hal Ehwal Ugama Islam Malaysia yang membincangkan isu alkohol dalam makanan, minuman, pewangi dan ubat-ubatan pada 14 hingga 16 Julai 2011 telah bersetuju memutuskan seperti berikut:

Setiap minuman arak adalah mengandungi alkohol. Walau bagaimanapun bukan semua alkohol itu adalah arak. Alkohol yang diperolehi dari proses pembuatan arak, hukumnya haram dan najis.

Manakala alkohol yang diperolehi bukan melalui proses pembuatan arak hukumnya tidak najis, tetapi haram (tidak boleh) diminum dalam bentuk aslinya kerana ia adalah racun dan boleh membunuh.

Minuman ringan yang diproses/dibuat bukan dengan tujuan untuk menghasilkan arak dan mempunyai alkohol di bawah aras 1\% v/v adalah harus (boleh) diminum.

Manakala minuman ringan yang dibuat dengan niat dan cara yang sama seperti proses membuat arak, sama ada mengandungi banyak atau sedikit alkohol atau alkoholnya disuling adalah haram diminum.

Makanan atau minuman yang mengandungi alkohol secara semulajadi seperti buah-buahan, kekacang atau bijirin serta perahannya, atau alkoholyang terkandung itu terjadi secara sampingan semasa proses pembuatan makanan atau minuman adalah tidak najis dan harus (boleh) dimakan/diminum.

Makanan atau minuman yang mengandungi bahan perisa atau pewarna yang mengandungi 
alkohol untuk tujuan penstabil adalah harus(boleh) digunakan sekiranya alkoholitu bukan dihasilkan dari proses pembuatan arak dan kuantiti alkohol dalam produkakhir ituadalah tidakmemabukkan dan kadar alkohol tidak melebihi $0.5 \%$.

Daripada kenyataan fatwa di atas, kita dapat melihat kadar piawaian alkohol yang dibenarkan dalam makanan mestilah tidak melebihi $0.5 \%$ atau maksimumnya $1 \%$. Hakikatnya, penulis kurang bersetuju dengan kenyataan fatwa tersebut memandangkan ia tidak praktikal bahkan ia boleh menghasilkan penentuan hukum yang tidak konsisten. Sanggahan ini diasaskan kepada beberapa alasan:

Pertama; kebanyakanmakanan halalyang siap diproses sekarang termasuklah yang dihasilkan secara tradisional, mengandungi kandungan etanol adalah jauh melebihi daripada kadar yang ditetapkan tersebut sedangkan ia dimakan oleh masyarakat Islam tanpa was-was. Keterangan mengenai hal ini dapat dilihat dalam rajah berikut berdasarkan kajian terhadap kandungan etanol dalam tapai:

\begin{tabular}{|c|c|c|c|}
\hline \multicolumn{4}{|c|}{ Kandungan alkohol (etanol) \% } \\
\hline Hari & Tapai pulut & Tapai ubi kayu & Tapai MARDI \\
\hline 0 & 3 & 3.4 & 1.5 \\
\hline 1 & 3.4 & 2.8 & 1.6 \\
\hline 2 & 5.2 & 3.3 & 1.9 \\
\hline
\end{tabular}

Sumber: Institusi Penyelidikan dan Kemajuan Pertanian Malaysia (MARDI), $1983^{31}$

Kedua; penetapan kadar tidak melebihi $1 \%$ juga adalah tidak konsisten dan tidak boleh dianggap sebagai illah pengharaman sesuatu makanan beralkohol. Sebaliknya, 'illah sebenar kepada pengharaman makanan beralkohol ialah menerusi pengesahan ia mampu memabukkan (iskār) terutamanya berdasarkan kajian saintifik. Ini dapat diterangkan menerusi analogi di antara hukum

31 Merican, Z \& Yeoh., Q.L (1983), "Penyediaan Tapai secara Moden," Teknologi makanan MARDI, no. 1, (1983): h. 10-11. 
arak bir dan tapai. Kedua-duanya mengandungi kandungan etanol yang hampir sama iaitu kira-kira 5\%. Namun, hukum keduaduanya adalah berbeza, bukan disebabkan kandungan etanol, tetapi kerana kemampuan salah satu daripadanya iaitu bir untuk memabukkan seseorang yang meminumnya. Oleh itu, 'illah sebenar kepada pengharaman makanan \& minumam beralkohol bukanlah kandungan etanol yang wujud di dalamnya, tetapi kemampuan makanan tersebut untuk menyebabkan simptom kemabukan.

Walau bagaimanapun, penulis juga tidak boleh menafikan bahawa usaha untuk menghadkan kandungan etanol dalam sesuatu makanan halal adalah penting kerana ia menyebabkan kemabukan jika melebihi kadar yang sepatutnya. Dalam hal ini, kita perlu memahami terdapat sekurang-kurang 3 jenis penggunaan alkohol dalam makanan iaitu : ${ }^{32}$

Pertama: Perahan pelbagai buah-buahan, susu pekat, ragi (yis) dan lain-lain yang mengandungi alkohol dalam kuantiti yang sedikit iaitu tidak melebihi 5\% kecuali perahan anggur yang kadangkadang mencapai 10\%. Makanan yang terhasil daripada bahanbahan ini, tidak dikategorikan sebagai kumpulan beralkohol dan memabukkan. Kedua: Bahan-bahan makanan yang dimasukkan alkohol dalam kuantiti yang sedikit bertujuan melarutkan bahan yang tidak larut di dalam air seperti pewarna, pengawet, perasa dan lain-lain. Ketiga: Bahan-bahan makanan yang dimasukkan minuman beralkohol yang memabukkan ke dalamnya seperti brandi, koniak, rawm dan lain-lain. Bahan-bahan ini yang dikenali sebagai arak dimasukkan bagi tujuan untuk menimbulkan citarasa yang menarik dan digemari oleh sesetengah pengguna.

Bagi kategori yang pertama dan kedua, hukumnya adalah harus memandangkan ia pada hakikatnya tidak menyebabkan kemabukan dan tujuan penggunaannya adalah baik. Sebaliknya, hukum penggunaan alkohol bagi kategori ketiga adalah haram kerana produk yang terhasil adalah arak berdasarkan tujuan penghasilannya dan sifat minuman tersebut yang mampu

32 Temubual bersama En. Dzulkifly Mat Hashim, Ketua Makmal Produk dan Proses Inovasi, Institut Penyelidikan Produk Halal, Universiti Putra Malaysia,pada 13 Julai 2009 bersamaan hari Isnin pada jam 2.30 petang. 
memabukkan. Sehubungan dengan ini, En. Dzulkifly Mat Hashim menolak pandangan sesetengah pihak yang mengatakan harus memakan makanan yang dicampurkan dengan arak dengan anggapan arak tersebut telah meruap setelah dipanaskan. Ini kerana, cecair arak sebenarnya tidak mudah meruap sekalipun dipanaskan selama beberapa jam sepertimana yang ditunjukkan menerusi satu kajian yang dilakukan oleh sebuah badan rasmi di Amerika Syarikat. ${ }^{33}$ Pandangan ini dikemukakan bagi menjawab dakwaan bahawa ada yang mengatakan arak yang dicampurkan dalam masakan akan meruap setelah dipanaskan.

\section{PIAWAIAN ALKOHOL DARI SUDUT PERUBATAN DAN SAINS}

Secara umumnya, kadar piawaian alkohol dalam makanan dari aspek perubatan menetapkan bahawa seseorang dianggap sebagai mabuk jika kandungan alkohol dalam darahnya (BAC) mencapai $0.08 \mathrm{~g} / 100 \mathrm{ml}$. Namun demikian, tahap kemabukan atau kadar pengambilan alkohol yang menyebabkan seseorang menjadi mabuk serta kadar kandungan alkohol yang diserap dalam darah adalah berbeza di antara satu individu dengan individu yang. ${ }^{34}$ Justeru itu, terdapat beberapa faktor yang perlu diberikan perhatian dalam menentukan kandungan alkohol dalam darah. Faktor tersebut adalah seperti berikut: ${ }^{35}$

i. Kepekatan alkohol yang diambil Tahap kemabukan adalah berbeza di antara satu individu dengan individu lain jika kepekatan atau konsentrasi alkohol yang diambil adalah berbeza.

ii. Berat badan

Semakin ringan berat badan, semakin mudah seseorang

33 Temubual bersama En. Dzulkifly Mat Hashim, Ketua Makmal Produk dan Proses Inovasi, Institut Penyelidikan Produk Halal, Universiti Putra Malaysia pada 13 Julai 2009 bersamaan hari Isnin pada jam 2.30 petang.

34 Dzulkifly Mat Hashim \& Nurul Hayati Abdul Hamid, "Penjenisan Alkohol dan Kesan Penggunaannya Dalam Makanan dan Minuman," Jurnal Halal, (2008), h. 30.

35 Ibid., h. 32-33. 
mendapat kesan kemabukan atau keracunan pada kuantiti alkohol yang diambil. Kandungan alkohol yang dikesan dalam darah adalah lebih rendah bagi individu yang bertubuh besar berbanding individu yang bertubuh kecil.

iii. Kadar pengambilan

Kepekatan alkohol dalam darah juga bergantung kepada kuantiti pengambilan alkohol dan kadar tubuh badan yang memetabolismakannya. Kadar pengambilan alkohol yang lebih tinggi berbanding kadar penguraian akan menyebabkan kesan pengumpulan darah dan meningkatkan kandungan alkohol dalam darah.

iv. Jantina

Secara umum, kaum wanita mempunyai kandungan lemak yang tinggi dalam badan dan kurang kandungan air. Oleh itu, jika seseorang wanita dan lelaki yang mempunyai berat badan yang sama, mengambil kandungan alkohol yang sama, maka wanita berkenaan akan mempunyai kandungan alkohol dalam darah yang lebih tinggi berbanding lelaki.

v. Umur

Kesan kandungan alkohol dalam darah lebih ketara bagi individu yang berumur.

vi. Makanan

Makanan yang diambil bersama-sama minuman beralkohol menyebabkan kelambatan kepekatan alkohol iaitu kesan keracunan yang berlaku.

\section{KESIMPULAN}

Terdapat beberapa konklusi berkaitan penetapan kadar piawaian alkohol dalam makanan yang dapat dinyatakan di sini.

1. Arak dan alkohol adalah dua entiti yang berbeza berdasarkan perbezaan kesan daripada kedua-duanya. Arak menyebabkan kemabukan manakala alkohol seperti etanol menyebabkan keracunan yang boleh membawa kematian. 
2. Proses penghasilan arak dan alkohol adalah sama pada dasarnya kerana masing-masing dihasilkan menerusi proses penapaian atau fermentasi iaitu penguraian kanji atau gula dengan bantuan yis. Namun demikian, pengeluar alkohol yang dibenarkan dalam Islam mestilah tidak ada hubungan dengan penghasilan arak agar ianya tidak dipergunakan untuk menghasilkan arak sepertimana yang dapat difahami menerusi konsep Sadd al-Dharī'ah.

3. Penentuan kadar piawaian alkohol atau etanol yang dibenarkan dalam Islam mestilah dibuat berasaskan faktor hukum atau 'illah yang jelas iaitu kemampuannya untuk menyebabkan kemabukan dan bukannya sematamata mengikut kadar peratusan tertentu. Sebagai contoh, peratusan etanol 5\% dalam tapai adalah masih diharuskan kerana ia tidak mampu menyebabkan pemakannya menjadi mabuk sedangkan arak bir yang juga mengandungi kandungan etanol 5\% adalah diharamkan kerana ia memabukkan.

4. Dari sudut kajian sains, potensi berlakunya kemabukan kepada seseorang juga boleh dipengaruhi oleh konsentrasi atau kepekatan alkohol dalam makanan yang diambil, kadar pengambilan, berat badan, jantina, umur dan pengambilan alkohol bersama makanan atau secara bersendirian. Dalam hal ini, kajian masih dijalankan oleh kumpulan penyelidik UPM yang diketuai oleh En. Dzulkifly Mat Hashim mengenai sejauhmana kadar peratusan alkohol yang dibenarkan dalam makanan dapat ditentukan berdasarkan elemen yang disenaraikan di atas.

5. Dakwaan kadar piawaian alkohol yang dibenarkan dalam makanan seperti sebanyak $0.01 \%, 0.1 \%, 1 \%$ seperti yang dapat dilihat dalam beberapa fatwa JAKIM sebenarnya perlu dikaitkan dengan 'illah kemabukan agar ia tidak bercanggah dengan realiti produk makanan sekarang yang rata-rata mengandungi kadar peratusan etanol yang lebih daripada itu. 
Penentuan Piawaian Alkohol Dalam Makanan Yang Dibenarkan Dari Perspektif Islam 